\title{
Herbage and Essential Oil Yield of Two Lemmon Grass (Cymbopogon Citratus) Varieties as Affected by Harvesting Cycle and Number of Tillers Per Planting Slips at Wondo Genet, Southern Ethiopia
}

\author{
Werotaw Sisay Yeshitila \\ Ethiopian Institute of Agricultural Research, Wondo Genet Agricultural Research Center, P.O box 198, \\ Shashamane, Ethiopia
}

*Corresponding Author: Werotaw Sisay Yeshitila, Ethiopian Institute of Agricultural Research, Wondo Genet Agricultural Research Center, P.O box 198, Shashamane, Ethiopia

\begin{abstract}
The experiment was conducted to determine harvesting cycle and appropriate number of tiller per planting slip using two different Lemmon grass varieties for better herbal and essential oil yield during 2017/2018 cropping season at Wondo Genet Agricultural Research Center. The design of the experiment was factorial RCBD design in three replications and the treatments of the experiment include combination of two Lemmon grass varieties with four level of number of tiller per planting slip (one, two, three and four tiller number per planting slip). Data on yield and yield components were collected and subjected to analysis of variance using SAS software version 9.3. Differences between means were assessed using least significant difference at 5\% probability level. Results of the experiment showed that the interaction factors (Lemmon grass variety and number of tillers per planting slip) were non-significant for all parameters. However, there was significant variation between two Lemmon grass varieties in plant height, number of leaf per hill, fresh leaf weight, and essential oil yield where the higher values were recorded at WG-Lomisar-Java variety. Between the first and second harvesting cycles, there was variation in plant height and the higher values $(133.79 \mathrm{~cm})$ were obtained at second harvest. Moreover, due to variation in number tiller per planting slip, there were significant and decreasing trend as number of tillers per planting slip increased from one to four for plant height, number of leaf per hill, number of tiller per plant, essential oil content, and leaf fresh weight while there was increasing trend for survival count. Therefore, we recommend variety WG-Lomisar-Java and planting slips having fewer number of tiller for fresh leaf weight and essential oil yield. For more a comprehensive result, the experiment should be repeated and more harvesting cycles should be considered further.
\end{abstract}

Keywords: Lemmon grass, essential oil, planting material, harvest cycle

\section{INTRODUCTION}

Lemongrass (Cymbopogon citratus (DC) Stapf) is a perennial aromatic grass that belongs to family Poaceae (Robbins, 1983). More than 140 species were reported among which Cymbopogon citratus (DC) Stapf is known for its aromatic herb and essential oil yield. Lemongrass is widely cultivated in the tropics and subtropics areas of the world (Punam et al., 2012). Scholars indicated that fresh herbs of Lemmon grass can be used medicinally and essential oil used as input for various industrial products (Tamuli et al., 2012). It is one of the prioritized and recognized aromatic plants in Ethiopia for herbal and essential oil yield. Currently, three varieties of Lemmon grass have been released recently and being under scaling up. According to Kassahun et.al. (2014), different Lemmon grass varieties can be grown for both herbage as well as essential oil yield in different geographical areas in Ethiopia. Besides, Bekele (2017) reported various Lemmon grass chemical compounds from which the most was citral ( $\alpha$-Citra and $\beta$-Citral) which is used in the synthesis of vitamins A \& E, [3 ionone, methyl ionone, synthetic violets and non-toxic adhesives besides its use in perfumery and flavor industries (Robbins, 1983). However, herbal, essential oil yield as well as chemical constitutes of this important aromatic plant affected by genotype (Kassahun et.al., 2014), plant part, age and drying methods (Bekele, 2017) and other environmental as well as agronomic management practices (Lulie and Chala, 2016). Lemmon grass is plant that can be propagated either by vegetative 
propagation method using slips or by mass propagation protocols depending on purpose of production, availability of planting materials and quality aspects during production. Moreover, despite Lemmon grass is important aromatic plant in Ethiopia and some agronomic practices have been identified and documented, no effort was done in identifying appropriate number of tiller used for field propagation. Knowing appropriate number of tillers per slip for planting believed to help better survival, growth and yield. Therefore, this experiment was initiated with the objective of determining harvesting cycle and number of tillers per slips for planting two Lemmon grass varieties for better herbal and essential oil yield.

\section{MATERIAL AND MeTHODS}

\subsection{Site Description of Study Area}

The experiment was conducted at Wondo Genet Agricultural Research Center, Southern Ethiopia during 2017 to 2018 cropping season. The experimental site is geographically located at $07^{\circ} 192^{\prime}$ North latitude, $38^{\circ} 382^{\prime}$ 'East longitude and an altitude of $1876 \mathrm{~m}$.a.s.l. The site receives mean annual rainfall of $1000 \mathrm{~mm}$ with minimum and maximum temperature of 12.02 and $26.72^{\circ} \mathrm{c}$, respectively. The soil texture of testing location was sandy clay loam with soil $\mathrm{pH}$ of 6.4. The major crops grown in the area include sugarcane, khat, maize, avocado, coffee, banana, haricot bean.

\subsection{Experimental Materials, Design, and Treatments}

Two varieties of lemon grass (Lomisar-I \&WG-Lomisa-Java) and four kinds of tiller number per planting slip were (Slip with one tiller, two tillers, three tillers and four tillers) were arranged in a factorial Randomized Complete Block Design (RCBD) with three replications. Treatments of the experiment include:

1. Lomisa-I with one tiller per planting slip

2. Lomisa-I with two tillers per planting slip

3. Lomisa-I with three tillers per planting slip

4. Lomisa-I with four tillers per planting slip

5. WG-Lomisa-Java with one tiller per planting slip

6. WG-Lomisa-Java with two tillers per planting slip

7. WG-Lomisa-Java with three tillers per planting slip

8. WG-Lomisa-Java with four tillers per planting slip

Area of experimental plot was $3 \mathrm{~m} \times 3 \mathrm{~m}$ and spacing of $60 \mathrm{~cm}$ between both plants and rows was maintained during the experiment resulting five rows and five plants per plot. Respective spacing of $1.5 \mathrm{~m}$ and $1 \mathrm{~m}$ was maintained between any two replications and plots respectively. Healthy slips from well grown clumps of lemon grass maintained at wondo Genet Agricultural Research Center were used for planting in well prepared experimental field. No fertilizer and chemical pesticide applied during experiment. All required cultural practices done as required.

\subsection{Data Collection and Analysis}

Two harvest cycles have been considered during data collection. The first harvest was conducted after four months of planting and the second harvest after two months of the first harvest. Each time harvesting was done by cutting the plant $10 \mathrm{~cm}$ above the ground level with the help of sterilized sickles. Data on number of plant height, number of leaf/tiller, survival count, number of tiller/hill, fresh leaf weight $(\mathrm{kg} / \mathrm{plot})$, fresh leaf weight $(\mathrm{t} / \mathrm{ha})$, essential oil content $(\%)$ and essential oil yield (t/ha) were recorded critically. Fresh leaf weight per plot data $(\mathrm{kg} / \mathrm{plot})$ was converted to fresh leaf weight per hectare data $(t / h a)$ for analysis. EO content was determined on fresh weight basis $(\mathrm{w} / \mathrm{w})$ from $300 \mathrm{~g}$ of herbage biomass harvested from the middle rows of a plot, excluding the border rows and border plants. Essential oil was determined by hydro-distillation as illustrated by Guenther (1972). All collected data were subjected to analysis of variance (ANOVA) using SAS computer software version 9.3. Differences between means were assessed by using of the least significance difference (LSD) test at $\mathrm{P}<0.05$. 


\section{RESULTS AND DISCUSSION}

\subsection{Plant Height $(\mathbf{C m})$}

Analysis of variance showed that plant height was significantly affected $(\mathrm{p}<0.001)$ by variety, number of tillers per slip and harvest cycle (Table 1). The longest significant plant height $(182.40 \mathrm{~cm})$ was obtained from WG-Lomisa-Java and the lowest $(63.24 \mathrm{~cm})$ at Lomisa-I variety (Table 2). The difference between the two varieties might be due to difference genetic factor of the varieties as WGLomisar-Java has longer internodes' and more leaf length than Lomisa-I. Besides, plant height was higher at second harvest cycle than the first harvest cycle (Table 2). This might be due to uniform harvest of the plant that might initiated new shoot growth as the newly emerged plant parts get growth resources, like water, nutrient and sun light, readily that otherwise goes to the older (harvested) plant part. Moreover, as number of tillers per planting slip increased from one to four, Lemmon grass plant height was significantly reduced from $133.88 \mathrm{~cm}$ to $111.48 \mathrm{~cm}$ (Table 2). This might be due to competition for nutrients that associated with plant growth, as more number of tillers requires more nutrient than lower tiller number.

\subsection{Number of Leaf Per Hill}

Analysis of variance showed that leaf number per hill was significantly affected by variety $(p<0.001)$ and number of tiler per planting slip $(\mathrm{p}<0.01)$, but did not affected by harvest cycle and interaction factors ( $p>0.05$ ) (Table 1). The highest number of leaf per hill (130.38) was recorded at WG-LomisarI and the lowest (95.03) at Lomisar-I variety (Table 2). Fewer tiller number per planting slip resulted higher leaf number per hill than more tiller number per planting slip treatments (Table 2). This might be because of increase in plant height obtained at less tiller number per planting slip treatments. This is similar with the reports of Lulie and Chala (2016) who indicated more leaf number per hill from widely spaced Lemmon grass than those narrowly spaced once. Besides, more tiller number per planting slip treatments might came across resource competition for growth resources than less tiller number per planting slip treatments.

\subsection{Survival Count}

ANOVA revealed no significant effects $(p>0.05)$ of varieties, harvesting cycle, number of tiller per planting slip treatments and interaction factors (Table 1). This implies that genotype, environment and management practices did not brought significant variation in survival rate of Lemmon grass during experimental period.

Table1. ANOVA of two Lemmon grass varieties evaluated for two-harvest cycles and four number of tillers per planting slip used for planting

\begin{tabular}{|c|c|c|c|c|c|c|c|c|}
\hline Source & DF & PH & NOL & SUC & EOC & NOT & LFWTH & EOYTHA \\
\hline Rep & 2 & $67.30^{\mathrm{NS}}$ & $834.82 \mathrm{NS}$ & $3.58^{\mathrm{NS}}$ & $0.0237^{*}$ & $171.09^{\mathrm{N}}$ & $0.034^{\mathrm{NS}}$ & $0.0027^{* * *}$ \\
\hline $\mathbf{C L}$ & 1 & $5776.07^{* * *}$ & $382.93 \mathrm{NS}$ & $00.00^{\mathrm{NS}}$ & $0.0001^{\mathrm{NS}}$ & $361.74^{\mathrm{NS}}$ & $0.003 \mathrm{NS}^{* * *}$ & $0.00044^{\mathrm{NS}}$ \\
\hline VAR & 1 & $170404.07^{* * *}$ & $14981.68^{* *}$ & $18.75^{\mathrm{NS}}$ & $0.0012^{\mathrm{NS}}$ & $6.84^{\mathrm{NS}}$ & $5.420^{* * *}$ & $0.02651^{* *}$ \\
\hline $\mathbf{N T}$ & 3 & $1491.6^{* * *}$ & $3847.39^{* *}$ & $14.97^{\mathrm{NS}}$ & $0.047^{* * *}$ & $273.83^{*}$ & $0.124^{*}$ & $0.00013^{\mathrm{NS}}$ \\
\hline $\begin{array}{c}\text { CLVAR } \\
\text { T }\end{array}$ & 10 & $30.43^{\mathrm{NS}}$ & $346.61^{\mathrm{NS}}$ & $19.69^{\mathrm{NS}}$ & $0.0010^{\mathrm{NS}}$ & $43.55^{\mathrm{NS}}$ & $0.022^{\mathrm{NS}}$ & $0.00001^{\mathrm{NS}}$ \\
\hline Error & 30 & 151.57 & 516.61 & 8.47 & 0.003 & 94.49 & 0.033 & 0.00012 \\
\hline CV & & 8.98 & 20.17 & 14.77 & 15.94 & 36.75 & 24.49 & 21.15 \\
\hline
\end{tabular}

NS=not significant; * **, and $* * *$ significant at $P \leq 0.05, P \leq 0.01$ and $P \leq 0.001$ probability levels respectively; Rep = Replication $; D F=$ degree of freedom; $C L=$ Harvest cycle; VAR =Variety; $N T=$ Number of tillers; $C V=$ coefficient of variance; $P H=$ Plant height $(\mathrm{cm}) ;$ LOL=Number of leaf per hill;SUC= Survival count; EOC=Essential oil content $(\%) ;$ NOT=Number of tillers/plant; LFWTHA=Fresh leaf weight $(t / h a) ; E O Y T H A=$ Essential oil yield (t/ha)

\subsection{Number of Tiller Per Plant}

Similar to the case of survival count, number of tiller per plant did not significantly influenced ( $>0.05$ ) by varieties, harvesting cycle and interaction factors (Table 1). However, number of tiller per planting slip treatments significantly influenced number of tiller per plant $(\mathrm{p}<0.05)$ (Table 1$)$. 
However, number of tiller per plant was numerically higher at Lomisar-I and at second harvest cycle compared to their respective factors. On the other hand, as number of tiller per planting slip increased from one to four, number of tiller per plant significantly decreased from 32.25 to 21.55 (Table 2). This could be a good indicator that more planting slip with more number of tiller could resulted more tiller number per plant that might increase biomass yield of the plant.

\subsection{Fresh Leaf Weight (t/ha)}

ANOVA showed that fresh leaf weight was significantly varied between the two Lemmon grass varieties $(p<0.001)$ as well as among number of tiller per planting slip treatments $(p<0.05)$ but did not affected by harvesting cycle and interaction factors (Table 1). The higher significant value were obtained at WG-Lomisar-Java variety (1.08t/ha) and at one tiller number per planting slip treatment $(0.88 \mathrm{t} / \mathrm{ha})$ (Table 2). Similarly Kassahun et.al. (2014) also reported variation in fresh leaf weight of Lemmon grass varieties. Furthermore, the higher fresh leaf weight obtained at one tiller number per planting slip might be due to few competition for growth resources that contributed increase in plant height, number of tiller per plant and number of leaf per hill and it this could be a good indicator in choosing economically important planting material.

Table2. Mean performance of yield and yield components of two lemon grass varieties as affected by harvest cycle and number of tillers per planting slip.

\begin{tabular}{|c|c|c|c|c|c|c|c|}
\hline Source & PH & NOL & SUC & EOC & NOT & LFWTHA & EOYTHA \\
\hline \multicolumn{7}{|c|}{ Lemmon Grass Varieties } \\
\hline Lomisar-I & $63.24^{\mathrm{b}}$ & $95.04^{\mathrm{b}}$ & $20.33^{\mathrm{a}}$ & $0.36^{\mathrm{a}}$ & $26.83^{\mathrm{a}}$ & $0.41^{\mathrm{b}}$ & $0.03^{\mathrm{b}}$ \\
\hline Lomisar-Java & $182.40^{\mathrm{a}}$ & $130.38^{\mathrm{a}}$ & $19.08^{\mathrm{a}}$ & $0.37^{\mathrm{a}}$ & $26.01^{\mathrm{a}}$ & $1.08^{\mathrm{a}}$ & $0.08^{\mathrm{a}}$ \\
\hline LSD(0.05) & 6.5 & 13.4 & NS & NS & NS & 0.11 & 0.01 \\
\hline \multicolumn{7}{|c|}{ Harvesting Cycle } \\
\hline Cycle 1 & $111.85^{\mathrm{b}}$ & $109.88^{\mathrm{a}}$ & $19.71^{\mathrm{a}}$ & $0.37^{\mathrm{a}}$ & $23.7^{\mathrm{a}}$ & $0.74^{\mathrm{a}}$ & $0.05^{\mathrm{a}}$ \\
\hline Cycle 2 & $133.79^{\mathrm{a}}$ & $115.53^{\mathrm{a}}$ & $19.71^{\mathrm{a}}$ & $0.37^{\mathrm{a}}$ & $29.2^{\mathrm{a}}$ & $0.75^{\mathrm{a}}$ & $0.05^{\mathrm{a}}$ \\
\hline LSD(0.05) & 6.5 & NS & NS & NS & NS & NS & $\mathrm{NS}$ \\
\hline \multicolumn{7}{|c|}{ Number of Planting Tiller } \\
\hline One Tiller & $137.88^{\mathrm{a}}$ & $136.03^{\mathrm{a}}$ & $19.83^{\mathrm{ab}}$ & $0.445^{\mathrm{a}}$ & $32.25^{\mathrm{a}}$ & $0.88^{\mathrm{a}}$ & $0.057^{\mathrm{a}}$ \\
\hline Two Tillers & $123.29^{\mathrm{b}}$ & $113.77^{\mathrm{b}}$ & $20.00^{\mathrm{ab}}$ & $0.393^{\mathrm{b}}$ & $28.28^{\mathrm{ab}}$ & $0.75^{\mathrm{ab}}$ & $0.054^{\mathrm{a}}$ \\
\hline Three Tillers & $118.63^{\mathrm{bc}}$ & $108.24^{\mathrm{bc}}$ & $18.17^{\mathrm{ab}}$ & $0.322^{\mathrm{c}}$ & $23.72^{\mathrm{b}}$ & $0.71^{\mathrm{b}}$ & $0.051^{\mathrm{a}}$ \\
\hline Four Tillers & $111.48^{\mathrm{c}}$ & $92.79^{\mathrm{c}}$ & $20.83^{\mathrm{a}}$ & $0.312^{\mathrm{c}}$ & $21.55^{\mathrm{b}}$ & $0.64^{\mathrm{b}}$ & $0.050^{\mathrm{a}}$ \\
\hline LSD(0.05) & 9.19 & 18.95 & 2.43 & 0.049 & 8.10 & 0.15 & $\mathrm{NS}$ \\
\hline CV & 8.98 & 20.17 & 14.77 & 15.94 & 36.75 & 24.49 & 21.15 \\
\hline CL*VAR*NT & $\mathrm{NS}$ & $\mathrm{NS}$ & $\mathrm{NS}$ & $\mathrm{NS}$ & $\mathrm{NS}$ & $\mathrm{NS}$ & $\mathrm{NS}$ \\
\hline
\end{tabular}

$N S=$ not significant $; C V=$ Coefficient of variance LSD = Least significant difference; Means followed by the same letters with in a column for a given treatment are not significantly different at $p \leq 5 \%$ level of significance

\subsection{Essential Oil Content (w/w, fresh based (\%))}

Analysis of variance (ANOVA) indicated that essential oil content was significantly affected $(\mathrm{p}<0.001)$ by number of tiller per planting slip, but did not affected by variety, harvesting cycle as well as interaction factors ( $>>0.05)$ (Table 1). The higher significant essential oil content was obtained at one tiller number per planting slip treatment and the value followed a reducing trend as number of tiller per planting slip increased (Table 2). This might be due to the fact that at higher tiller number per planting slip, there might be competition for resources so that the plant might struggle for survival and vegetative growth rather than synthesizing essential oil.

\subsection{Essential Oil Yield (t/ha)}

Unlike essential oil content, essential oil yield was significantly affected by Lemmon grass varieties $(\mathrm{p}<0.001)$ but did not affected by harvesting cycle, number of tiller per planting slip and interaction factors ( $>0.05)$ (Table 1). The higher essential oil yield was obtained at WG-Lomisa-Java variety $(0.08 \mathrm{t} / \mathrm{ha})$ while the lower significant was recorded at Lomisar-I variety $(0.03 \mathrm{t} / \mathrm{ha})$. This might be because of difference in morphological growth of the varieties.

\section{SUMMARY AND CONCLUSION}

Knowledge of genotype difference, selection of planting material for propagation, and harvesting cycle for perennial plants like Lemmon grass is important for economic yield. In the case of present 
study, there was significant variation between two Lemmon grass varieties in plant height, number of leaf per hill, fresh leaf weight, and essential oil yield and WG-Lomisar-Java variety was superior in all of the mentioned parameters. The experiment also clearly indicated presence of variation between in plant height determined at two different harvesting cycles and the second harvesting resulted higher plant height. Moreover, due to variation in number tiller per planting slip, there were significant and decreasing trend as number of tillers per planting slip increased from one to four for plant height, number of leaf per hill, number of tiller per plant, essential oil content, and leaf fresh weight while there was increasing trend for survival count. Therefore, we recommend variety WG-Lomisar-Java together with planting slips having fewer numbers of tillers for fresh leaf weight and essential oil yield. For more a comprehensive result, the experiment should be repeated and more harvesting cycles should be considered.

\section{REFERENCES}

[1] Bekele W. 2017. Influence of harvesting age and drying periods on herbage yield, essential oil content, oil yield and citral yield of two lemongrass (Cymbopogon citratus (DC) Stapf) varieties at Wondo Genet, South Ethiopia. MSc Thesis Submitted to the School of Plant Sciences and Horticulture Hawassa University College of Agriculture.

[2] Kassahun BM., EgataDF, Yosef WB. \& Lulsseged T. 2014. Variability in Lemongrass (Cymbopogon citratus (DC) Stapf.) Genotypes for Agronomic and Chemical Characters in Ethiopia. International Journal of Green and Herbal Chemistry 3(4):1482-1489.

[3] Lulie, B. and Chala, M. 2016. Influence of Plant Population Density on Growth and Yield of Lemon Grass (Cymbopogon citratus L.) at Wondo Genet, South Ethiopia. Academic Research Journal of Agricultural Science and Research. 4(3): 76-84.

[4] Punam P., Kumar R., Sharma S. and Atul D.2012. Effect of Organic Management Treatments on the Productivity and Quality of Lemmon Grass. Journal of Organic Systems. 7(2).

[5] Robbins S.1983. Selected markets for the essential oils of Lemongrass, Citronella and Eucalyptus. Trop Prod Inst, London.

[6] Tamuli P., Saikia M. and Boruah P.2012. Dynamics of Essential oil of Lemmon Grass and Palmarosa under Rust Disease Indices. Journal of Medical Research. 1(3):034-037.

Citation: Werotaw Sisay Yeshitila, (2019). "Herbage and Essential Oil Yield of Two Lemmon Grass (Cymbopogon Citratus) Varieties as Affected by Harvesting Cycle and Number of Tillers Per Planting Slips at Wondo Genet, Southern Ethiopia" International Journal of Research Studies in Agricultural Sciences (IJRSAS), 5(2), pp.18-22, http://dx.doi.org/10.20431/2454-6224.0502003

Copyright: () 2019 Authors. This is an open-access article distributed under the terms of the Creative Commons Attribution License, which permits unrestricted use, distribution, and reproduction in any medium, provided the original author and source are credited. 